Discussion Paper No. 959

\author{
THE WELFARE EFFECTS \\ OF ATTRACTING FOREIGN \\ DIRECT INVESTMENT \\ IN THE PRESENCE OF UNEMPLOYMENT
}

Yoshitomo Ogawa

Yoshiyasu Ono

February 2016

The Institute of Social and Economic Research

Osaka University

6-1 Mihogaoka, Ibaraki, Osaka 567-0047, Japan 


\title{
The Welfare Effects of Attracting Foreign Direct Investment in the Presence of Unemployment*
}

\author{
Yoshitomo Ogawa ${ }^{\dagger}$ and Yoshiyasu Ono ${ }^{\ddagger}$
}

February 2016

\begin{abstract}
We develop a $2 \times 2 \times 2$ model with the following features: (1) one sector is perfectly competitive while the other is oligopolistic; (2) one country has unemployment while the other attains full employment; (3) oligopolists move internationally; and (4) the ownership of each oligopolist is internationally shared. The welfare effects of various tax-cum-subsidies are examined. If the oligopolistic sector is capital intensive, subsidizing the oligopolists' profits, inflows, production or employment is more likely to harm the country. The number of domestically based oligopolists, the volume of domestic demand for the oligopoly-produced commodity, and the country's ownership share of oligopolists also influence the effect.
\end{abstract}

Keywords: Corporate Taxation, Production Subsidies, Unemployment, Oligopoly JEL Classification: F12, F13, H25, H71, R38

\footnotetext{
${ }^{*}$ We would like to appreciate a financial support from the Joint Usage/Research Center Program by the Ministry of Education, Culture, Sports, Science and Technology, Japan. Financially supports by the Grants-in-Aid for Scientific Research from the Japan Society for the Promotion of Science to Ogawa (26380385) and to Ono (15H05728 and 22530178) are also gratefully acknowledged.

${ }^{\dagger}$ Faculty of Economics, Kinki University, 3-4-1 Kowakae, Higashiosaka, Osaka 577-8502, JAPAN; E-mail: yogawa@kindai.ac.jp

${ }^{\ddagger}$ Institute of Social and Economic Research, Osaka University, 6-1 Mihogaoka, Ibaraki, Osaka 5670047, JAPAN; E-mail: ono@iser.osaka-u.ac.jp.
} 


\section{Introduction}

To boost domestic employment and income, many countries implement policies to retain domestic firms and attract foreign firms, particularly when facing the threat of unemployment. Typical policies include location subsidies and corporate tax cuts. Sweden, Germany, Ireland, and Canada respectively lowered their corporate tax rates from 56.6\%, $60.0 \%, 50.0 \%$, and $48.3 \%$ in 1983 to $22.0 \%, 30.2 \%, 12.5 \%$, and $26.1 \%$ in 2013 (see Tax Foundation Website, 2013). Location subsidies are widespread in Japan, being offered by 43 out of 47 prefectural governments (see Hamada, 2008).

However, using these policies to attract firms does not necessarily benefit a country in which there is unemployment. For example, the inflow of capital-intensive firms will cause employment to decline because of the Stolper-Samuelson effect. Moreover, if the firms are mostly owned by foreigners, increase in profits promoted by tax cuts and subsidies offered to the firms will not return to home people.

To examine the welfare effects of attracting foreign firms to a country that has unemployment, we develop a general equilibrium $2 \times 2 \times 2$ model in which one sector is oligopolistic and the other is perfectly competitive. ${ }^{1}$ The model features oligopolists' location choice between two countries, international ownership of oligopolists' equities, and unemployment caused by wage rigidities. Haufler and Mittermaier (2011), Lahiri and Ono (2011), and Haufler and Stähler (2013) examine international location choice by oligopolists, but they consider neither foreign ownership nor unemployment. Although Hucka and Konrad (2003) explore the effect of production subsidies by introducing an international distribution of firm ownership into the model of Brander and Spencer (1985), they ignore location choice and unemployment. Leite-Monteiro et al. (2003), Kreickemeier (2005), and Ogawa, Sato, and Tamai (2006) analyze taxes and trade policies in an economy that has unemployment. In their models, however, there is neither oligopolistic behavior, firms' location choice, nor foreign ownership of firms.

There are few studies that incorporate firm location choice, foreign ownership, and unemployment simultaneously. Johdo and Hashimoto (2009) analyze the effect of corporate tax on employment and aggregate demand in a two-country model where unemployment is caused by insufficient aggregate demand, and monopolistic firms produce heterogeneous commodities using only labor. Exbrayat et al. (2012) examine international capital-tax competition by assuming technology with fixed amounts of labor and capital inputs which are unrelated to the level of output. In our model, by contrast, unemployment is caused by wage rigidities, and Cournot oligopolists produce homogenous commodities using constant-returns-to-scale technology with respect to labor and capital. This setting enables us to find the role of factor intensity in the effect of corporate taxcum-subsidy on employment. Furthermore, we examine the effect of corporate tax on not only employment but also welfare. The welfare effects of other policy instruments, such

\footnotetext{
${ }^{1}$ Lahiri and Ono (1995) develop a similar model.
} 
as production subsidies, location subsidies, employment subsidies, and minimum-wage cuts, are also analyzed.

Our main results are summarized thus. If the oligopolistic sector is capital-intensive, (i) the more oligopolists there are in a country, (ii) the lower demand for the oligopolyproduced commodity a country has or (iii) the lower share of oligopolists a country owns, the more likely the country is made better off by a corporate tax and worse off by location and production subsidies. Thus, policies that attract foreign firms may make the country worse off. This result has implications for countries that aim to stimulate their economies by attracting more foreign firms.

\section{The Model}

We consider an economy in which there are two countries, home and foreign, and in which two commodities are produced and internationally traded. One of the production sectors is competitive and the other is a Cournot oligopoly. In the oligopoly sector, there are $N$ firms, of which $n$ are located in the home country and $n^{*}$ are in the foreign country; hence,

$$
n+n^{*}=N(=\text { constant }) .
$$

Throughout, the superscript * denotes variables of the foreign country. Both commodities are produced using two factors, labor and capital, based on constant-returns-to-scale technology. The two factors are both internationally immobile. Production technology in the competitive sector $(a)$ and that in the oligopoly sector $(o)$ are

$$
\begin{gathered}
A^{(*)}=f\left(k_{a}^{(*)}\right) L_{a}^{(*)}, \quad x^{(*)}=g\left(k_{o}^{(*)}\right) L_{o}^{(*)}, \\
f^{\prime}<0, \quad f^{\prime \prime}<0 ; \quad g^{\prime}>0, \quad g^{\prime \prime}<0,
\end{gathered}
$$

where $A^{(*)}$ and $x^{(*)}$ are the outputs of the competitive and oligopolistic sectors, respectively, $L_{i}^{(*)}$ and $K_{i}^{(*)}$ are labor and capital inputs in sector $i$, and $k_{i}^{(*)}$ is

$$
k_{i}^{(*)} \equiv K_{i}^{(*)} / L_{i}^{(*)} \text { for } i=a, o .
$$

Using the competitively produced product as numeraire, from (2), the competitive sector's profit maximization and the oligopolistic sector's cost minimization respectively lead to

$$
\begin{gathered}
f^{\prime}\left(k_{a}^{(*)}\right)=r^{(*)}, \quad f\left(k_{a}^{(*)}\right)-f^{\prime}\left(k_{a}^{(*)}\right) k_{a}^{(*)}=w^{(*)}, \\
\frac{w^{(*)}}{r^{(*)}}=\frac{g\left(k_{o}^{(*)}\right)}{g^{\prime}\left(k_{o}^{(*)}\right)}-k_{o}^{(*)}, \\
\Rightarrow \quad r^{(*)}=r\left(w^{(*)}\right), \quad k_{a}^{(*)}=k_{a}\left(w^{(*)}\right), \quad k_{o}^{(*)}=k_{o}\left(w^{(*)}\right),
\end{gathered}
$$


where $w^{(*)}$ is the wage rate and $r^{(*)}$ is the capital rent. From (2) and (3), the unit cost function for each home (or foreign) oligopolist $c^{(*)}$ is

$$
c^{(*)}=c\left(w^{(*)}\right) \equiv \frac{w^{(*)}+r\left(w^{(*)}\right) k_{o}\left(w^{(*)}\right)}{g\left(k_{o}\left(w^{(*)}\right)\right)}=\frac{r\left(w^{(*)}\right)}{g^{\prime}\left(k_{o}\left(w^{(*)}\right)\right)} .
$$

From (3) and (4), we obtain

$$
\begin{gathered}
f^{\prime \prime} d k_{a}^{(*)}=d r^{(*)}=-\frac{1}{k_{a}^{(*)}} d w^{(*)}, \quad d k_{o}^{(*)}=-\frac{\left(g^{\prime}\right)^{2} w^{(*)}}{g g^{\prime \prime} r^{(*)}}\left(\frac{1}{w^{(*)}}+\frac{1}{k_{a}^{(*)} r^{(*)}}\right) d w^{(*)}, \\
d c^{(*)}=\frac{k_{a}\left(w^{(*)}\right)-k_{o}\left(w^{(*)}\right)}{g\left(k_{o}^{(*)}\right) k_{a}\left(w^{(*)}\right)} d w^{(*)}
\end{gathered}
$$

The utility function is quasi-linear and the second derivative of the demand function for the oligopoly-produced commodity is zero; hence, one can ignore the second-order demand effect. The inverse demand function for the oligopoly-produced commodity satisfies

$$
p=p\left(D+D^{*}\right), \quad p^{\prime}\left(D+D^{*}\right)=\text { const. }<0,
$$

where $D$ (or $D^{*}$ ) is home (foreign) demand for the oligopoly-produced commodity. Market equilibrium for the oligopoly-produced commodity implies

$$
D+D^{*}=n x+n^{*} x^{*}
$$

The after-tax profits of the oligopolists located in each country are

$$
\left(1-\theta^{(*)}\right) \pi^{(*)}-\varepsilon^{(*)}=\left(1-\theta^{(*)}\right)\left(p\left(n x+n^{*} x^{*}\right)-c\left(w^{(*)}\right)+s^{(*)}\right) x^{(*)}-\varepsilon^{(*)},
$$

where $\pi^{(*)}$ represents gross profits, $\theta^{(*)}$ is each country's corporate tax rate, $\varepsilon^{(*)}$ is a location tax, and $s^{(*)}$ is each country's production subsidy. The profit-maximizing condition is

$$
p^{\prime} x^{(*)}+p\left(n x+n^{*} x^{*}\right)-c\left(w^{(*)}\right)+s^{(*)}=0 .
$$

From (7) and (8), we obtain

$$
\pi=-p^{\prime} x^{2}, \quad \pi^{*}=-p^{\prime}\left(x^{*}\right)^{2}
$$

Because all oligopolists can freely move between the two countries to maximize profits, after-tax profits are internationally equalized. Therefore,

$$
(1-\theta) \pi-\varepsilon=\left(1-\theta^{*}\right) \pi^{*}-\varepsilon^{*}, \quad(1-\theta) d \pi-(\pi d \theta+d \varepsilon)=\left(1-\theta^{*}\right) d \pi^{*}-\left(\pi^{*} d \theta^{*}+d \varepsilon^{*}\right) .
$$

In the home country, although capital is fully utilized, labor is not fully employed because of wage rigidity,

$$
w=\bar{w}
$$


where $\bar{w}$ is exogenously given and above the market-clearing level. In the foreign country, the two factors are fully utilized. Thus,

$$
\begin{gathered}
L_{a}+n L_{o}=L, \\
k_{a}(\bar{w}) L_{a}+n k_{o}(\bar{w}) L_{o}=\bar{K}, \\
L_{a}^{*}+(N-n) L_{o}^{*}=\bar{L}^{*}, \\
k_{a}^{*}\left(w^{*}\right) L_{a}^{*}+(N-n) k_{o}^{*}\left(w^{*}\right) L_{o}^{*}=\bar{K}^{*},
\end{gathered}
$$

where $\bar{K}$ and $L$ denote the home country's capital endowment and labor demand, and $\bar{L}^{*}$ and $\bar{K}^{*}$ are the foreign country's factor endowments. Applying (1) to the above equations and totally differentiating the results yields

$$
\begin{gathered}
d L_{a}+n d L_{o}^{*}+n d L_{o}+L_{o} d n=d L, \\
k_{a} d L_{a}+n k_{o} d L_{o}+n k_{o} d L_{o}^{*}+k_{o} L_{o} d n=0, \\
d L_{a}^{*}+(N-n) d L_{o}^{*}+(N-n) d L_{o}^{*}-L_{o}^{*} d n=0, \\
k_{a}^{*} d L_{a}^{*}+L_{a}^{*} d k_{a}^{*}+(N-n) k_{o}^{*} d L_{o}^{*}-k_{o}^{*} L_{o}^{*} d n+(N-n) L_{o}^{*} d k_{o}^{*}=0 .
\end{gathered}
$$

Because we assume that each household owns the same share of equities across all oligopolists, equity ownership is not biased toward the home country. The equity share is $\alpha$ for home country households and $\alpha^{*}(=1-\alpha)$ for foreign ones. Tax revenues are paid to, and subsidy funds are collected from, each country's households as lump-sum amounts. Because all oligopolists earn the same net profits, as shown in (10), home and foreign national income, $Y$ and $Y^{*}$, are

$$
\begin{gathered}
Y=\bar{w} L+r \bar{K}+n(\theta \pi+\varepsilon-s x)+\alpha N[(1-\theta) \pi-\varepsilon], \\
Y^{*}=w^{*} \bar{L}^{*}+r^{*} \bar{K}^{*}+n^{*}\left(\theta^{*} \pi^{*}+\varepsilon^{*}-s^{*} x^{*}\right)+\alpha^{*} N\left[\left(1-\theta^{*}\right) \pi^{*}-\varepsilon^{*}\right] .
\end{gathered}
$$

Having set up the model structure, we will analyze the effects of various policies when both countries initially choose the same policy settings. From (9) and (10), $x=x^{*}$ if $\theta=\theta^{*}$ and $\varepsilon=\varepsilon^{*}$. Therefore, if $\theta=\theta^{*}, \varepsilon=\varepsilon^{*}$, and $s=s^{*}$, from $(8), c(\bar{w})=c^{*}\left(w^{*}\right)$, which leads to $w^{*}=\bar{w}$. By applying this property to (2) and (3) one finds that initially

$$
\begin{gathered}
x=x^{*}, c(\bar{w})-s=c\left(w^{*}\right)-s^{*} \text { if } \theta=\theta^{*} \text { and } \varepsilon=\varepsilon^{*} \\
\bar{w}=w^{*}, r=r^{*}, k_{a}=k_{a}^{*}, k_{o}=k_{o}^{*}, L_{o}=L_{o}^{*} \text { if } \theta=\theta^{*}, \varepsilon=\varepsilon^{*} \text { and } s=s^{*} .
\end{gathered}
$$

Changes in the two countries' welfare $W$ and $W^{*}$ are

$$
\left(1 / \lambda^{(*)}\right) d W^{(*)}=d Y^{(*)}-D^{(*)} p^{\prime} d\left(D+D^{*}\right)
$$

where $\lambda^{(*)}$ is the marginal utility of each country's income. The welfare effects of the policies are examined in the neighborhood where all policy variables are zero. Therefore, by totally differentiating (3), (6), and (13), substituting the results of $d\left(D+D^{*}\right)$ and $d Y^{(*)}$ 
into the above equation, and making use of (10), (14) and the property that $d n+d n^{*}=0$ from (1), we obtain

$$
\begin{aligned}
(1 / \lambda) d W= & \left(L+\bar{K} r^{\prime}\right) d \bar{w}+\bar{w} d L+n[(\pi d \theta+d \varepsilon)-x d s] \\
& -\alpha N[(\pi d \theta+d \varepsilon)-d \pi]-D p^{\prime}\left(n d x+n^{*} d x^{*}\right) \\
\left(1 / \lambda^{*}\right) d W^{*}= & \left(\bar{L}^{*}+\bar{K}^{*} r^{* \prime}\right) d w^{*}+n^{*}\left[\left(\pi^{*} d \theta^{*}+d \varepsilon^{*}\right)-x^{*} d s^{*}\right] \\
& -\alpha^{*} N\left[\left(\pi^{*} d \theta^{*}+d \varepsilon^{*}\right)-d \pi^{*}\right]-D^{*} p^{\prime}\left(n d x+n^{*} d x^{*}\right) .
\end{aligned}
$$

From (5) and the last two equations in (11), we find that the change in foreign factor income $\left(\bar{L}^{*}+\bar{K}^{*} r^{* \prime}\right) d w^{*}$ to satisfy

$$
\left(\bar{L}^{*}+\bar{K}^{*} r^{* \prime}\right) d w^{*}=\left(\bar{K}^{*}-k_{a}^{*} \bar{L}^{*}\right) f^{\prime \prime} d k_{a}^{*}=n^{*} L_{o}^{*}\left(k_{o}^{*}-k_{a}^{*}\right) f^{\prime \prime} d k_{a}^{*} .
$$

\section{Corporate Taxes}

In this section, we ignore the location and production taxes, $\varepsilon^{(*)}$ and $s^{(*)}$, to focus on the welfare effects of corporate taxes, $\theta$ and $\theta^{*}$. We assume that both countries initially choose the same tax rate. By using (1), (8), (9), (10), and (14), we obtain

$$
\begin{gathered}
\left.x_{\theta}\right|_{\theta=\theta^{*}}=\frac{n^{*} x}{2(1-\theta)(1+N)}>0,\left.\quad x_{\theta}^{*}\right|_{\theta=\theta^{*}}=-\frac{(1+n) x}{2(1-\theta)(1+N)}<0, \\
\left.x_{\theta^{*}}\right|_{\theta=\theta^{*}}=-\frac{n^{*} x^{*}}{2\left(1-\theta^{*}\right)(1+N)}<0,\left.\quad x_{\theta^{*}}^{*}\right|_{\theta=\theta^{*}}=\frac{(1+n) x^{*}}{2\left(1-\theta^{*}\right)(1+N)}>0, \\
\left.\frac{\partial\left(n x+n^{*} x^{*}\right)}{\partial \theta}\right|_{\theta=\theta^{*}}=\left.n x_{\theta}\right|_{\theta=\theta^{*}}+\left.n^{*} x_{\theta}^{*}\right|_{\theta=\theta^{*}}=-\frac{n^{*} x}{2(1-\theta)(1+N)}<0, \\
\left.\frac{\partial\left(n x+n^{*} x^{*}\right)}{\partial \theta^{*}}\right|_{\theta=\theta^{*}}=\left.n x_{\theta^{*}}\right|_{\theta=\theta^{*}}+\left.n^{*} x_{\theta^{*}}^{*}\right|_{\theta=\theta^{*}}=\frac{n^{*} x}{2(1-\theta)(1+N)}>0,
\end{gathered}
$$

where $x_{\theta^{(*)}}^{(*)} \equiv \partial x^{(*)} / \partial \theta^{(*)}$. In what follows, subscripts denote partial derivatives.

Let us discuss the implications of (17). A rise in the home corporate tax lowers the net profits of domestic oligopolists and motivates some of them to move abroad. This changes foreign factor prices, so that the marginal cost of each foreign-based oligopolist increases and its output decreases. By contrast, the output of each domestically based oligopolist increases because $w$ is fixed at $\bar{w}$ and, thus, so too is its marginal cost. Because foreign-based oligopolists' marginal costs increase while those of domestically based oligopolists remain unchanged, world output decreases. A rise in the foreign corporate tax rate encourages foreign firms to move to the home country. It boosts the output of each foreign-based oligopolist by lowering its marginal cost. Each domestically based oligopolist's output decreases because its marginal cost is unchanged. Unlike a rise in the home corporate tax rate, a rise in the foreign corporate tax rate lowers some firms' (i.e., the foreign-based firms') marginal costs, leaving others' (i.e., the domestically based firms') unchanged, which raises world output. This result yields the following proposition. 
Proposition 1. Suppose that the home and foreign countries initially set the same corporate tax rate. If the country with (without) unemployment raises its tax rate, world output of the oligopoly-produced commodity decreases (increases).

Next, we examine the welfare effects of the home country increasing its corporate tax rate $\theta$ from 0 . From (1), (9), and (17), we obtain

$$
\begin{aligned}
& \left.\pi_{\theta}\right|_{\theta=\theta^{*}}=-\frac{p^{\prime} n^{*} x^{2}}{(1-\theta)(1+N)}>0,\left.\quad \pi_{\theta}^{*}\right|_{\theta=\theta^{*}}=\frac{p^{\prime}(1+n) x^{2}}{(1-\theta)(1+N)}<0, \\
& \left.\pi_{\theta^{*}}\right|_{\theta=\theta^{*}}=\frac{p^{\prime} n^{*}\left(x^{*}\right)^{2}}{\left(1-\theta^{*}\right)(1+N)}<0,\left.\quad \pi_{\theta^{*}}^{*}\right|_{\theta=\theta^{*}}=-\frac{p^{\prime}(1+n)\left(x^{*}\right)^{2}}{\left(1-\theta^{*}\right)(1+N)}>0 .
\end{aligned}
$$

From (1), (9), (17), and (18), $d W$ in (15) satisfies

$$
\begin{array}{r}
\left.\frac{1}{\lambda} \frac{d W}{d \theta}\right|_{\theta=\theta^{*}=0}=-\frac{p^{\prime} x}{2(1+N)}\{2 x[n N(1-\alpha)+n-\alpha N]-D(N-n)\} \\
+\left.\bar{w} \frac{d L}{d \theta}\right|_{\theta=\theta^{*}=0} .
\end{array}
$$

Larger values of $n$ and smaller values of $\alpha$ and $D$ contribute to the positivity of $d W /\left.d \theta\right|_{\theta=\theta^{*}=0}$. From (2), (3), (5), (8), (12), (14), and (17), we obtain

$$
\left.\frac{d L}{d \theta}\right|_{\theta=\theta^{*}}=\frac{x \Phi}{2(1-\theta)\left(k_{o}-k_{a}\right) k_{a}} \lessgtr 0 \Leftrightarrow k_{o} \lessgtr k_{a},
$$

where $\Phi \equiv \frac{L_{a}^{*} g p^{\prime}}{f^{\prime \prime}}+\frac{(N-n)\left(k_{o}^{*}-k_{a}^{*}\right)^{2}}{g(1+N)}+\frac{(N-n) p^{\prime}\left(k_{a}^{*}+\frac{w^{*}}{r^{*}}\right)^{2} L_{o}^{*}\left(g^{\prime}\right)^{3}}{r^{*} g g^{\prime \prime}}>0$.

(See Mathematical Appendix for the derivation.) Equations (19) and (20) yield the next proposition.

Proposition 2. Suppose that the oligopolistic sector is capital intensive (labor intensive) and that neither country initially levies corporate tax. The larger (smaller) is the number of oligopolists located in the home country, the lower (higher) is the share of equities owned by the home country, or the lower (higher) is the home country's demand for the oligopoly-produced commodity, the more likely is the home country to benefit (suffer) from levying corporate tax.

According to Proposition 1, if the home country levies corporate tax, the relative price of the oligopoly-produced commodity increases, which raises demand for the competitively produced commodity. Therefore, if the competitive sector is more labor intensive than the oligopolistic sector, domestic employment increases, which benefits the home country. In turn, the rise in the price of the oligopoly-produced commodity lowers the home country's consumer surplus. The extent of this loss rises with the home country's demand for the oligopoly-produced commodity. Corporate tax revenue is higher, 
the more domestic oligopolists there are. Corporate tax lowers oligopolists' net profits. Therefore, the lower is the share of the oligopolists' equities owned by the home country, the smaller is the loss of revenues from equities. Proposition 2 summarizes these predictions.

Many countries, particularly when they have unemployment, lower their corporate tax rates in an attempt to retain their domestic firms and attract foreign direct investment to stimulate their economies. However, according to Proposition 2, a country that attracts capital-intensive or exporting firms by lowering its corporate tax rate (from a low initial level) makes itself worse off.

Next, we investigate the effect on foreign welfare. From (2), (5), (8), (16) and (17), the effect on factor payments in the foreign country is

$$
\left.\left(\bar{L}^{*}+\bar{K}^{*} r^{* \prime}\right) w_{\theta}^{*}\right|_{\theta=\theta^{*}}=-\frac{n^{*} p^{\prime} x^{2}}{2(1-\theta)} .
$$

(See Mathematical Appendix for the derivation.) Applying (1), (9), (17), (18), and (21) to $d W^{*}$ in (15) and rearranging the result yields the following effect on foreign welfare $W^{*}:$

$$
\begin{aligned}
\left.\frac{1}{\lambda^{*}} \frac{d W^{*}}{d \theta}\right|_{\theta=\theta^{*}=0} & =-\frac{p^{\prime} x^{*}}{2(1+N)}\left\{x^{*}\left[(1+N) n^{*}-2 \alpha^{*} N(1+n)\right]-D^{*} n^{*}\right\} \\
& =-\frac{p^{\prime} x^{*}}{2(1+N)}\left[n^{*}\left(x^{*}+D+2 \alpha^{*} N x^{*}\right)-2 \alpha^{*} N(1+N) x^{*}\right] .
\end{aligned}
$$

These two expressions for $d W^{*} /\left.d \theta\right|_{\theta=\theta^{*}=0}$ are used to obtain the following proposition.

Proposition 3. The larger (smaller) is the number of foreign-based oligopolists, the lower (higher) is the share of equities owned by the foreign country, or the lower (higher) is the foreign country's demand for the oligopoly-produced commodity, the more likely is the foreign country to benefit (suffer) from the home country levying corporate tax.

There is no effect on foreign employment because the foreign country attains full employment. The intuition behind the other predictions is the same as for Proposition 2.

Next, we examine the welfare effects of the foreign country levying corporate tax. From (1), (9), (17), and (18), $d W$ in (15) satisfies

$$
\left.\frac{1}{\lambda} \frac{d W}{d \theta^{*}}\right|_{\theta=\theta^{*}=0}=-\frac{p^{\prime} n^{*} x}{2(1+N)}(D-2 \alpha N x)+\left.\bar{w} \frac{d L}{d \theta^{*}}\right|_{\theta=\theta^{*}=0} .
$$

From (2), (3), (5), (8), (12), (14), (17), and (20), we obtain

$$
\left.\frac{d L}{d \theta^{*}}\right|_{\theta=\theta^{*}}=-\left.\frac{d L}{d \theta}\right|_{\theta=\theta^{*}} \lessgtr 0 \Leftrightarrow k_{o} \gtrless k_{a} .
$$

(See Mathematical Appendix for the derivation of (23).) The sign of $d L /\left.d \theta^{*}\right|_{\theta=\theta^{*}}$ is the opposite of that of $d L /\left.d \theta\right|_{\theta=\theta^{*}}$. Equations (22) and (23) generate the following proposition. 
Proposition 4. Suppose that the oligopolistic sector is labor intensive (capital intensive). The lower (higher) is the share of equities owned by the home country, or the higher (lower) is the home country's demand for the oligopoly-produced commodity, the more likely is the home country to benefit (suffer) from the foreign country levying corporate tax.

The number of domestic oligopolists $n$ has nothing to do with the welfare effect of the foreign corporate tax rate $\theta^{*}$ because $\theta^{*}$ does not affect the home country's tax revenues. An increase in $\theta^{*}$ increases world output of the oligopoly-produced commodity, as stated in Proposition 1, and reduces its price. It raises the home country's consumer surplus and the magnitude of the increase depends positively on the home country's demand for the oligopoly-produced commodity. This is the opposite of the effect of the home country's corporate tax rate, $\theta$, as stated in Proposition 2. This is because an increase in $\theta$ lowers world output of the oligopoly-produced commodity, as stated in Proposition 1, and raises the oligopoly price.

Next, we examine the effect on foreign welfare. From (2), (5), (8), (16), and (17), we obtain

$$
\left.\left(\bar{L}^{*}+\bar{K}^{*} r^{* \prime}\right) w_{\theta^{*}}^{*}\right|_{\theta=\theta^{*}}=\frac{n^{*} p^{\prime}\left(x^{*}\right)^{2}}{2(1-\theta)} .
$$

(See Mathematical Appendix for this derivation.) Using this, (1), (9), (17), and (18), one finds that $d W^{*}$ in $(15)$ is

$$
\left.\frac{1}{\lambda^{*}} \frac{d W^{*}}{d \theta^{*}}\right|_{\theta=\theta^{*}=0}=-\frac{n^{*} p^{\prime} x^{*}}{2(1+N)}\left[x^{*}\left(1+N-2 \alpha^{*} N\right)+D^{*}\right] .
$$

This result is used to establish the following proposition.

Proposition 5. The higher (lower) is the foreign country's demand for the oligopolyproduced commodity, or the lower (higher) is the share of equities owned by the foreign country, the more likely is the foreign country to benefit (suffer) from levying corporate tax.

From Proposition 1, an increase in $\theta^{*}$ increases world output of the oligopoly-produced commodity and reduces the price, which raises the foreign country's consumer surplus. From this follows the first property of Proposition 5. The second property is valid because the foreign country suffers smaller losses from equity earnings the lower is its equity share. In particular, when $\alpha^{*}=0$, an increase in $\theta^{*}$ unambiguously makes the foreign country better off. 


\section{Location Taxes}

The effects of location taxes $\varepsilon$ and $\varepsilon^{*}$ are basically the same as those of corporate taxes, $\theta$ and $\theta^{*}$. Firstly, from (10) one obtains

$$
\begin{aligned}
d \pi-\frac{\pi}{1-\theta} d \theta & =d \pi^{*}-\frac{\pi^{*}}{1-\theta^{*}} d \theta^{*} & & \text { when } \theta=\theta^{*} \text { and } \varepsilon=\varepsilon^{*}=0, \\
d \pi-d \varepsilon & =d \pi^{*}-d \varepsilon^{*} & & \text { when } \theta=\theta^{*}=0,
\end{aligned}
$$

implying that their effects on the location choice are the same if $d \varepsilon^{(*)}=\left[\pi^{(*)} /(1-\right.$ $\left.\left.\theta^{(*)}\right)\right] d \theta^{(*)}$. Moreover, the two policies affect neither the marginal conditions for profit maximization (8) nor the gorss profits given in (9). Because the effects of $\theta$ and $\theta^{*}$ on each firm's output $x$ and $x^{*}$ and on total output $n x+n^{*} x^{*}$ are derived from (8), (9) and (10), the effects of $d \varepsilon^{(*)}$ on them are respectively the same as those of $\left[\pi^{(*)} /\left(1-\theta^{(*)}\right)\right] d \theta^{(*)}$. Therefore, proposition 1 also applies to the case of location tax.

Proposition 6. Suppose that the home and foreign countries initially set the same location tax rate. If the country with (without) unemployment raises its tax rate, world output of the oligopoly-produced commodity decreases (increases).

The welfare effects of the two policies in the neighborhood where $\varepsilon=\varepsilon^{*}=0$ and $\theta=\theta^{*}=0$ are also the same to each other, as mentioned below. From (25) in which $\theta=\theta^{*}=0$, the effects of $d \varepsilon^{(*)}$ on $x, x^{*}$ and $n x+n^{*} x^{*}$ are respectively the same as those of $\pi^{(*)} d \theta^{(*)}$. From (8), the effects on $w^{*}$ of the policies appear through changes in $x$ and $x^{*}$. The effects on $L$ emerge through changes in $x, x^{*}, n x+n^{*} x^{*}$ and $w^{*}$ so as to satisfy (2), (3) and (12) (see Mathematical Appendix for details). Therefore, from (15), the effects of $d \varepsilon^{(*)}$ on $W$ and $W^{*}$ are the same as those of $\pi^{(*)} d \theta^{(*)}$.

Proposition 7. The welfare effects of location tax-cum-subsidy are equivalent to those of corporate tax-cum-subsidy; namely, Propositions 2-5 hold when location tax-cum-subsidy rather than corporate tax-cum-subsidy is used.

In sum, neither corporate tax nor location tax changes the first-order optimal conditions of firms while changes in the two taxes affect the location choice in the same way when $d \varepsilon^{(*)}=\pi^{(*)} d \theta^{(*)}$. Moreover, from (7), when $\varepsilon=\varepsilon^{*}=0$ and $\theta=\theta^{*}=0$, the effects of such changes in the two taxes on each country's tax revenue $n^{(*)}\left[\theta^{(*)} \pi^{(*)}+\varepsilon^{(*)}\right]$ are the same to each other. Therefore, the welfare effect of $d \varepsilon^{(*)}$ is equivalent to that of $\pi^{(*)} d \theta^{(*)}$.

\section{Production Subsidies}

This section examines the welfare effects of production subsidies $s$ and $s^{*}$. For simplicity, we ignore corporate taxes, $\theta$ and $\theta^{*}$, and location taxes, $\varepsilon$ and $\varepsilon^{*}$. From (1), (8), (9), and 
the properties on the first line of (14), we obtain

$$
\begin{gathered}
x_{s}=x_{s}^{*}=-\frac{1}{(1+N) p^{\prime}}>0, n x_{s}+n^{*} x_{s}^{*}=-\frac{N}{(1+N) p^{\prime}}>0, \pi_{s}=\pi_{s}^{*}=\frac{2 x}{1+N}>0 ; \\
x_{s^{*}}=x_{s^{*}}^{*}=0, \quad n x_{s^{*}}+n^{*} x_{s^{*}}^{*}=0, \quad \pi_{s^{*}}=\pi_{s^{*}}^{*}=0 .
\end{gathered}
$$

From (14), the marginal costs of domestic and foreign firms are equalized through the international movement of firms. Therefore, if the country with the fixed wage subsidizes production, each firm's marginal cost falls by the same amount, which raises each firm's output and profits. By contrast, if the country with flexible wages subsidizes production, firms' marginal costs, output, and profits are not affected. This result is summarized in the following proposition.

Proposition 8. If the country with unemployment subsidizes production, each firm's output and profits increase, whereas subsidization of production by the full-employment country has no effect on firms' output or profits.

From (1), the property given by the first line of (14), and (26), $d W$ in (15) is

$$
\left.\frac{1}{\lambda} \frac{d W}{d s}\right|_{s=s^{*}=0}=\left(\frac{N}{1+N}\right)\left\{x\left[2 \alpha-n\left(\frac{1+N}{N}\right)\right]+D\right\}+\left.\bar{w} \frac{d L}{d s}\right|_{s=s^{*}=0} .
$$

From (2), (3), (5), (12), (14), and (26), we obtain

$$
\left.\frac{d L}{d s}\right|_{s=s^{*}}=\frac{\Omega}{k_{a}\left(k_{a}-k_{o}\right)}
$$

$$
\text { where } \Omega \equiv \frac{N x_{s}\left(k_{a}^{*}-k_{o}^{*}\right)^{2}}{g}-\frac{L_{a}^{*} g}{f^{\prime \prime}}-\frac{(N-n)\left(g^{\prime}\right)^{3} L_{o}}{g g^{\prime \prime} r^{*}}\left(k_{a}^{*}+\frac{w^{*}}{r^{*}}\right)^{2}>0 \text {. }
$$

(See Mathematical Appendix for derivation of (28).) Because $\Omega>0$, the sign of $d L /\left.d s\right|_{s=s^{*}}$ depends on the sign of $\left(k_{a}-k_{o}\right)$. Equations (27) and (28) establish the following proposition.

Proposition 9. Suppose that the oligopolistic sector is capital intensive (labor intensive). The larger (smaller) is the number of domestic oligopolists, the lower (higher) is the share of equities owned by the home country, or the lower (higher) is the home country's demand for the oligopoly-produced commodity, the more likely is the home country to suffer (benefit) from subsidizing production.

The implications of these conditions are similar to those for the corporate tax-cumsubsidy mentioned in Proposition 2.

Next, we examine the effect of the home country's production subsidy on foreign welfare $W^{*}$. From (2), (3), (5), (16), and (26), we obtain

$$
\left(\bar{K}^{*} r^{* \prime}+\bar{L}^{*}\right) w_{s}^{*}=-n^{*} x^{*} .
$$


(See Mathematical Appendix for this derivation.) Therefore, using (1), (26), and (29), we rewrite $d W^{*}$ in (15) as

$$
\left.\frac{1}{\lambda^{*}} \frac{d W^{*}}{d s}\right|_{s=s^{*}=0}=\left(\frac{N}{1+N}\right)\left\{x^{*}\left[2 \alpha^{*}-n^{*}\left(\frac{1+N}{N}\right)\right]+D^{*}\right\} .
$$

We use this expression to establish the following proposition.

Proposition 10. The larger (smaller) is the number of foreign-based oligopolists, the lower (higher) is the share of equities owned by the foreign country, or the lower (higher) is the foreign country's demand for the oligopoly-produced commodity, the more likely is the foreign country to suffer (benefit) from the home country subsidizing production.

The implications of the conditions are clear from those in Propositions 2 and 8. Note that factor intensity does not matter because the foreign country achieves full employment and the factor-intensity condition determines the direction of a change in employment if unemployment arises.

Next, we examine the welfare effects of the foreign production subsidy $s^{*}$. Because $x$ and $x^{*}$ are unaffected by $s^{*}$, as shown in (26), neither the oligopoly price $p$ nor gross profits $\pi\left(=\pi^{*}\right)$ is affected by $s^{*}$. Therefore, from (15), we obtain

$$
\begin{gathered}
\left.\frac{1}{\lambda} \frac{d W}{d s^{*}}\right|_{s=s^{*}=0}=\left.\bar{w} \frac{d L}{d s^{*}}\right|_{s=s^{*}=0}, \\
\left.\frac{1}{\lambda^{*}} \frac{d W^{*}}{d s^{*}}\right|_{s=s^{*}=0}=\left(\bar{L}^{*}+\bar{K}^{*} r^{* \prime}\right) w_{s^{*}}^{*}-n^{*} x^{*} .
\end{gathered}
$$

The first equation shows that higher employment is the home country's sole source of increased welfare. From (2), (3), (5), (12), (14), (16), and (26), we obtain

$$
\begin{gathered}
\left.\frac{d L}{d s^{*}}\right|_{s=s^{*}}=\frac{\Gamma}{k_{a}\left(k_{o}-k_{a}\right)}, \quad \Gamma \equiv-\frac{L_{a}^{*} g}{f^{\prime \prime}}-\frac{\left(g^{\prime}\right)^{3} n^{*} L_{o}^{*}}{g^{\prime \prime} g r^{*}}\left(k_{a}^{*}+\frac{w^{*}}{r^{*}}\right)^{2}>0, \\
n^{*} x^{*}=\left(\bar{L}^{*}+\bar{K}^{*} r^{* \prime}\right) w_{s^{*}}^{*} .
\end{gathered}
$$

(See Mathematical Appendix for the derivation of these properties.) Equations (30) and (31) are used to establish the following proposition.

Proposition 11. If and only if the oligopolistic sector is capital intensive (labor intensive) does the foreign production subsidy benefit (harm) the home country. It does not affect foreign welfare in any case.

As shown by the upper line in (14), because the home country's wage rate is fixed at $\bar{w}$ and because oligopolists can move between countries, the foreign production subsidy affects neither oligopolists' marginal costs, production, nor profits. The movement of oligopolists from the home country to the foreign one reduces foreign production, and 
increases home production, of the competitively produced commodity. Therefore, if the oligopoly sector is capital intensive (or if the competitive sector is labor intensive), employment in the home country increases and the home country is better off. This is the only effect on home welfare because $\bar{w}, r(\bar{w})$, and $\pi\left(=\pi^{*}\right)$ do not vary.

Given that earnings from equities do not change, the effect on foreign welfare, if any, operates by affecting the foreign country's total factor income minus the tax burden for the production subsidy. Because $c(\bar{w})=c\left(w^{*}\right)-s^{*}\left(=\frac{L_{o}^{*} w^{*}+K_{o}^{*} r^{*}}{x^{*}}-s^{*}\right)$ as a result of the international movements of oligopolists, we have

$$
n^{*} x^{*} c(\bar{w})=n^{*} L_{o}^{*} w^{*}+n^{*} K_{o}^{*} r^{*}-n^{*} x^{*} s^{*}
$$

Therefore, from $x^{*}$ in (2), the two equations of the first line in (3), and the third and fourth equations in (11), total factor income $\bar{L}^{*} w^{*}+\bar{K}^{*} r^{*}$ minus the tax burden $n^{*} x^{*} s^{*}$ satisfies

$$
\bar{L}^{*} w^{*}+\bar{K}^{*} r^{*}-n^{*} x^{*} s^{*}=f\left(k_{a}^{*}\right) L_{a}^{*}+c(\bar{w}) g\left(k_{o}^{*}\right) n^{*} L_{o}^{*} .
$$

This value equals total foreign production when the oligopoly price is $c(\bar{w})$ instead of $p$. Furthermore, from (3) and (4), each oligopolist's cost minimization behavior leads to

$$
c(\bar{w}) g\left(k_{o}\left(w^{(*)}\right)\right)=w^{(*)}+r\left(w^{(*)}\right) k_{o}\left(w^{(*)}\right), \quad r\left(w^{(*)}\right)=c(\bar{w}) g^{\prime}\left(k_{o}\left(w^{(*)}\right)\right) .
$$

These equations are the same as those in the hypothetical case in which the price of this commodity is fixed at $c(\bar{w})$ and the firms behave competitively. Because the other sector is competitive and the optimal behavior is described by the first line of (3), the hypothetical income represented by (32) can be regarded as that prevailing in the abovementioned competitive economy when the relative price is fixed at $c(\bar{w})$. The envelope theorem implies that a marginal reallocation of the two factors between the two sectors would not change the value of (32), which equals the foreign net factor income of the current economy. Therefore, foreign welfare is not affected by a marginal change in $s^{*}$.

\section{Minimum-Wage Reduction and Employment Sub- sidies}

In this section, we examine the welfare effects of a reduction in the minimum wage $\bar{w}$ and an increase in the employment subsidy $z$ provided to the oligopoly sector in the home country. For simplicity, we assume that $\theta=\theta^{*}=\varepsilon=\varepsilon^{*}=s=s^{*}=0$. In this case, the second line of (3) and $Y$ in (13), respectively, become

$$
\begin{gathered}
\frac{\bar{w}-z}{r}=\frac{g\left(k_{o}\right)}{g^{\prime}\left(k_{o}\right)}-k_{o}, \\
Y=(\bar{w}-z) L+r \bar{K}+\alpha N \pi .
\end{gathered}
$$


These expressions imply that the effect of a reduction in $\bar{w}$ is the same as that of a rise in $z$.

From (8) and (14), in which $\theta=\theta^{*}=s=s^{*}=0$, we find

$$
d c=(1+N) p^{\prime} d x
$$

This equation, (5), (9), and (14) yield

$$
\begin{aligned}
& x_{\bar{w}}=x_{\bar{w}}^{*}=\frac{k_{a}-k_{o}}{(1+N) p^{\prime} g k_{a}}, \\
& \pi_{\bar{w}}=\pi_{\bar{w}}^{*}=-\frac{2 x\left(k_{a}-k_{o}\right)}{(1+N) g k_{a}} .
\end{aligned}
$$

If the oligopolistic sector is labor intensive $\left(k_{a}>k_{o}\right)$, a rise in $\bar{w}$ lowers each oligopolist's output and profits through the Heckscher-Ohlin mechanism.

From (1), the first equation in (5), (14), and (33), $d W$ given in (15) reduces to

$$
\frac{1}{\lambda} \frac{d W}{d z}=-\frac{1}{\lambda} \frac{d W}{d \bar{w}}=\frac{N\left(k_{a}-k_{o}\right)}{(1+N) g k_{a}}\left\{x\left[2 \alpha-n\left(\frac{1+N}{N}\right)\right]+D\right\}-\bar{w} \frac{d L}{d \bar{w}} .
$$

Because (12) and (14) lead to

$$
k_{a} d L=\left[N\left(k_{a}-k_{o}\right) L_{o \bar{w}}+N L_{o} k_{a \bar{w}}-N L_{o} k_{o \bar{w}}-\left(L+\bar{L}^{*}\right) k_{a \bar{w}}\right] d \bar{w},
$$

in which $L_{o \bar{w}}$ is derived from (2), (5), and (33), thus,

$$
L_{o \bar{w}}=\frac{k_{a}-k_{o}}{(1+N) p^{\prime} g^{2} k_{a}}+\frac{\left(g^{\prime}\right)^{3} L_{o} \bar{w}}{g^{2} g^{\prime \prime} r}\left(\frac{1}{\bar{w}}+\frac{1}{k_{a} r}\right),
$$

and $k_{a \bar{w}}$ and $k_{o \bar{w}}$ are found from (5), it follows that $d L / d \bar{w}$ satisfies

$$
\frac{d L}{d z}=-\frac{d L}{d \bar{w}}=-\frac{1}{k_{a}^{2}}\left[\frac{N\left(k_{a}-k_{o}\right)^{2}}{(1+N) p^{\prime} g^{2}}+\frac{L_{a}+L_{a}^{*}}{f^{\prime \prime}}+\frac{\left(g^{\prime}\right)^{3} N L_{o}}{g^{2} g^{\prime \prime} r}\left(k_{a}+\frac{\bar{w}}{r}\right)^{2}\right]>0 .
$$

Equations (34) and (35) are used to establish the following proposition.

Proposition 12. Suppose that the oligopolistic sector is labor intensive (capital intensive). The smaller (larger) is the number of domestic oligopolists, the higher (lower) is the share of equities owned by the home country, or the higher (lower) is the home country's demand for the oligopoly-produced commodity, the more likely is the home country to benefit from lowering wages and subsidizing employment.

If the oligopoly sector is labor intensive, the home country's employment subsidy increases each oligopolist's output, as shown in (33). It lowers the oligopoly price and increases the home country's consumer surplus. The magnitude of this benefit rises with the home country's demand for the oligopoly-produced commodity. The tax burden of 
financing the subsidy is smaller, the fewer domestic oligopolists there are. Because the subsidy increases every oligopolist's net profits, the larger share of equities the home country owns, the more earnings from equities it earns. The employment-creation effect is unambiguously positive because the subsidy motivates oligopolists to enter the country and employ more labor. Proposition 12 summarizes these predictions.

As is clear from (27) and (34), the welfare-improving conditions related to the employment subsidy, apart from its employment-creation effect, are the same as those related to the production subsidy. This is because the employment subsidy affects the home country's welfare by raising oligopoly production in the same way as does the production subsidy. $^{2}$

Next, we examine the effect on foreign welfare. From (5), the last two equations in (11), the second line in (14), and (16), we obtain

$$
\bar{L}^{*}+\bar{K}^{*} r^{* \prime}=\frac{\left(k_{a}^{*}-k_{o}^{*}\right) n^{*} L_{o}^{*}}{k_{a}^{*}}, \quad d w^{*}=d \bar{w} .
$$

From (1), (14), (33), and the above property, $d W^{*}$ in (15) is

$$
\frac{1}{\lambda^{*}} \frac{d W^{*}}{d z}=-\frac{1}{\lambda^{*}} \frac{d W^{*}}{d \bar{w}}=\frac{N\left(k_{a}^{*}-k_{o}^{*}\right)}{(1+N) g k_{a}^{*}}\left\{x^{*}\left[2 \alpha^{*}-n^{*}\left(\frac{1+N}{N}\right)\right]+D^{*}\right\} .
$$

From this, we establish the following proposition.

Proposition 13. Suppose that the oligopolistic sector is labor intensive (capital intensive). The smaller (larger) is the number of foreign-based oligopolists, the higher (lower) is the share of equities owned by the foreign country, or the higher (lower) is the foreign country's demand for the oligopoly-produced commodity, the more likely is the foreign country to benefit from the home country lowering wages and subsidizing employment.

The home country's employment subsidy affects foreign welfare by changing oligopoly production and the international movements of oligopolists. Therefore, apart from the employment-creation effect (which does not operate in the foreign country), the implications of the conditions under which the foreign country's welfare increases (stated in Proposition 13) are the same as those under which the home country's welfare increases (stated in Proposition 12).

\section{Numerical Examples}

From (19), (20), (27), (28), (34), and (35), we can respectively determine the conditions on the equity share, $\alpha$, required for the home country's corporate subsidy, production

\footnotetext{
${ }^{2}$ The employment-creation effect of the employment subsidy is different from that of the production subsidy. The former directly stimulates employment whereas the latter affects employment by raising output in the oligopoly sector. Therefore, the former effect unambiguously increases employment, as shown by (35), whereas the latter only does so when the oligopoly sector is labor intensive, as shown by (31).
} 
subsidy, and employment subsidy, to increase domestic welfare. They are

$$
\begin{gathered}
\left.\frac{d W}{d(-\theta)}\right|_{\theta=\theta^{*}=0}-\left.\lambda \bar{w} \frac{d L}{d(-\theta)}\right|_{\theta=\theta^{*}=0} \gtrless 0 \Leftrightarrow \alpha \\
\text { where }\left.\lambda \bar{w} \frac{d L}{d(-\theta)}\right|_{\theta=\theta^{*}=0} \gtrless 0 \Leftrightarrow k_{a} \gtrless k_{o}, \\
\left.\frac{d W}{d s}\right|_{s=s^{*}=0}-\left.\lambda \bar{w} \frac{d L}{d s}\right|_{s=s^{*}=0} \gtrless 0 \Leftrightarrow \alpha \gtrless \frac{n}{2}\left(\frac{N+1}{N}-\frac{D}{n x}\right), \\
\text { where }\left.\lambda \bar{w} \frac{d L}{d s}\right|_{s=s^{*}=0} \gtrless 0 \text { iff } k_{a} \gtrless k_{o}, \\
\left(k_{a}-k_{o}\right)\left(\frac{d W}{d z}-\lambda \bar{w} \frac{d L}{d z}\right) \gtrless 0 \quad \Leftrightarrow \quad \alpha \gtrless \frac{n}{2}\left(\frac{N+1}{N}-\frac{D}{n x}\right), \\
\text { where } \lambda \bar{w} \frac{d L}{d z}>0 .
\end{gathered}
$$

In this section, we present numerical examples of these conditions. We find the critical values of $\alpha$ based on ignoring the employment-creation effect. We do so because the magnitude of the employment effect depends on the marginal utility of income, the first and second derivatives of the production functions, and so on. Note that the welfare effects of corporate tax cuts and production subsidies deriving from employment creation are positive if and only if the oligopoly sector is labor intensive, whereas that of the employment subsidy is unambiguously positive. Therefore, the conditions relating to $\alpha$ are sufficient in those cases.

The examples are based on data on the automobile industry in 2014, the beer industry in 2013, and the Smartphone industry in 2014. However, our examples are only indicative of outcomes in these industries. This is because, whereas our model assumes that a commodity is produced using only local factors, in practice, many of the parts might be imported. Moreover, whereas our model assumes that all oligopolists have the same technology, the same market share, and the same equity share distribution across countries, in reality, these factors differ between firms. Thus, our examples are merely hypothetical examples based on market sizes and firm numbers that are similar to those of the three industries under consideration. To be specific, we assume the global number of firms $N$ to be $m / \rho$, where $\rho$ is the market share of the world's top $m$ firms in each industry, and we assume the number of domestic firms $n$ to be $\gamma \times(m / \rho)$, where $\gamma$ is the home country's share of global production.

\section{(a) Automobile Industry}

In 2014, the share of the top 10 firms in the automobile industry was about $68 \%$. Thus, we set $N$ to $15(\doteqdot 10 / 0.68)$. Total automobile production was about $90(=N x)$ million 
units. Thus, each firm's production $x$ is set to $6(=90 / 15)$ million units. Production and consumption levels in the top six countries are summarized in Table 1. The number of firms located in each country is assumed to be $N$ multiplied by the production share. For example, the number of firms located in China is assumed to be $4(\doteqdot 15 \times 24 / 90)$.

Substituting the values in Table 1 into (36) yields the conditions on $\alpha$ under which the subsidies make each country better off, apart from the effect that operates through employment creation. Table 2 shows the results. In China, for example, if the worldwide equity share is less than $57 \%$, corporate taxation (rather than subsidization) increases domestic welfare, apart from the effect that operates through employment creation. For the USA, the equity share must be less than 30\%. For the other countries, the critical shares are between those of the USA and China. Moreover, the employment-creation effect of corporate taxation is positive if the automobile industry is capital intensive. Therefore, taxing this industry should benefit the home country. In the USA, the welfare effect of the production subsidy (ignoring the employment-creation effect) is positive. However, the employment-creation effect is negative if the industry is capital intensive. Subsidizing employment clearly increases domestic welfare in the USA.

Table 1

\begin{tabular}{|c|ccc|}
\hline Country & $\begin{array}{c}\text { Production } \\
\text { (million units) }\end{array}$ & $\begin{array}{c}\text { Consumption } \\
\text { (million units) }\end{array}$ & $\begin{array}{c}\text { Number } \\
\text { of firms }\end{array}$ \\
\hline China & 24 & 23 & 4 \\
USA & 12 & 17 & 2 \\
Japan & 10 & 6 & 2 \\
Germany & 6 & 3 & 1 \\
Korea & 5 & 2 & 1 \\
India & 4 & 3 & 1 \\
(Sources. Statista: http://www.statista.com/statistics/316786/global-market-share-of-the-leading-automakers/; $)$
\end{tabular}
Global Note: http://www.globalnote.jp/post-3184.html; http://www.globalnote.jp/post-11249.html.

Table 2

\begin{tabular}{|c|cc|}
\hline Country & Corporate subsidy $^{3}$ & $\begin{array}{c}\text { Production subsidy } \\
\text { Employment subsidy }\end{array}$ \\
\hline China & $\alpha>0.572$ & $\alpha>0.216$ \\
USA & $\alpha>0.301$ & always beneficial \\
Japan & $\alpha>0.566$ & $\alpha>0.566$ \\
Germany & $\alpha>0.416$ & $\alpha>0.283$ \\
Korea & $\alpha>0.455$ & $\alpha>0.366$ \\
India & $\alpha>0.416$ & $\alpha>0.283$ \\
\hline
\end{tabular}

\footnotetext{
${ }^{3}$ Obviously, these conditions are opposite in the case of corporate tax.
} 


\section{(b) Beer Industry}

In 2013, the top 10 firms in the beer industry accounted for about $65 \%$ of the market. Thus, we set $N$ to $15(\doteqdot 10 / 0.65)$. Given world beer production of about $193(=N x)$ billion liters, each firm's production $x$ is calculated to be $13(\doteqdot 193 / 15)$ billion liters. Table 3 shows the approximate amounts of production and consumption for the world's top six countries. In the same way as for case (a), we calculate the number of firms located in each country, which is reported in the final column of Table 3.

Substituting the values in Table 3 into (36) yields the conditions on $\alpha$ under which the subsidies make each country better off, apart from the effect that operates through employment creation. Table 4 shows the results. As in the automobile industry, in all countries, corporate taxation increases domestic welfare, apart from the effect that operates through employment creation, if the worldwide equity share of each country is less than $30 \%$. The employment-creation effects of corporate taxes are positive if the beer industry is capital intensive. The welfare effects of production and employment subsidies are mixed.

Table 3

\begin{tabular}{|c|ccc|}
\hline Country & $\begin{array}{c}\text { Production } \\
\text { (billion liters) }\end{array}$ & $\begin{array}{c}\text { Consumption } \\
\text { (billion liters) }\end{array}$ & $\begin{array}{c}\text { Number } \\
\text { of firms }\end{array}$ \\
\hline China & 47 & 46 & 4 \\
USA & 22 & 24 & 2 \\
Brazil & 13 & 13 & 2 \\
Germany & 9 & 8 & 1 \\
Russia & 9 & 10 & 1 \\
Mexico & 8 & 7 & 1 \\
\hline
\end{tabular}

$\left(\begin{array}{c}\text { Sources. Business Insider: http://www.businessinsider.com/global-beer-industry-consolidation-2014-2; } \\ \text { Kirin Holdings: http://www.kirinholdings.co.jp/english/news/2014/0808_01.html, } \\ \text { http://www.kirinholdings.co.jp/english/news/2014/1224_01.html. }\end{array}\right)$

Table 4

\begin{tabular}{|c|cc|}
\hline Country & Corporate subsidy & $\begin{array}{c}\text { Production subsidy } \\
\text { Employment subsidy }\end{array}$ \\
\hline China & $\alpha>0.593$ & $\alpha>0.367$ \\
USA & $\alpha>0.444$ & $\alpha>0.145$ \\
Brazil & $\alpha>0.300$ & $\alpha>0.033$ \\
Germany & $\alpha>0.389$ & $\alpha>0.227$ \\
Russia & $\alpha>0.353$ & $\alpha>0.150$ \\
Mexico & $\alpha>0.407$ & $\alpha>0.266$ \\
\hline
\end{tabular}




\section{(c) Smartphone Industry}

In 2014, the top five firms in the Smartphone industry accounted for about $55 \%$ of the market. Hence, we set $N$ to $9(\doteqdot 5 / 0.55)$. Given world production of about $1220(=N x)$ million units in 2014, the amount of each firm's production $x$ is $136(\doteqdot 1220 / 9)$ million units. Table 5 shows the approximate amounts of production and consumption of the world's top two producing countries. In the same way as for case (a), we calculate the number of firms located in each country, which is reported in the final column of Table 5 .

Substituting the values in Table 5 into (36) yields the conditions on $\alpha$ under which the subsidies make each country better off, apart from the effect that operates through employment creation. Table 6 shows the results. In China, corporate tax and production tax are unambiguously beneficial, apart from the employment-creation effect. This is also the case for Vietnam if its worldwide equity share is less than $50 \%$, which is plausible. Moreover, from (20) and (28), the employment-creation effects of corporate tax and production tax are positive if these countries' industries are capital intensive. Therefore, corporate tax and production tax benefit these two countries. The welfare effect of an employment subsidy that operates through employment creation is unambiguously negative. Hence, for these two countries, the total welfare effect of an employment subsidy is ambiguous.

Table 5

\begin{tabular}{|c|ccc|}
\hline Country & $\begin{array}{c}\text { Production } \\
\text { (million units) }\end{array}$ & $\begin{array}{c}\text { Consumption } \\
\text { (million units) }\end{array}$ & $\begin{array}{c}\text { Number } \\
\text { of firms }\end{array}$ \\
\hline China & 970 & 420 & 7 \\
Vietnam & 110 & 10 & 1 \\
\hline
\end{tabular}

$\left(\begin{array}{l}\text { Sources. IDC: http://www.idc.com/getdoc.jsp?containerId=prUS25407215; http://www.idc.com/getdoc.jsp? } \\ \text { containerId=prHK25437515; http://www.idc.com/getdoc.jsp?containerId=prVN25480615; JEITA }(2015): \\ \text { Worldwide Production of Major Electronics. }\end{array}\right)$

Table 6

\begin{tabular}{|c|cc|}
\hline Country & Corporate subsidy & $\begin{array}{c}\text { Production subsidy } \\
\text { Employment subsidy }\end{array}$ \\
\hline China & always harmful & always harmful \\
Vietnam & always harmful & $\alpha>0.520$ \\
\hline
\end{tabular}

\section{Conclusion}

We have examined the welfare effects of a corporate tax, a location tax, a production subsidy, and an employment subsidy in a $2 \times 2 \times 2$ general equilibrium model with a 
perfectly competitive sector and an oligopolistic sector. Our model incorporates unemployment caused by wage rigidities, oligopolist-location choice between countries, and foreign ownership of oligopolists. We have derived the conditions under which a corporate tax-cum-subsidy, a location tax-cum-subsidy, a production tax-cum-subsidy, and an employment tax-cum-subsidy improve home and foreign welfare, respectively.

The literature on tax competition, as represented by, for example, Wilson (1986) and Wildasin (1988), shows that tax competition that reduces taxes is harmful to countries because the reduction in tax revenue from tax competition leads to an undersupply of public goods. By contrast, tax revenue is not an important factor in the welfare analysis based on our model because the tax revenue is returned to residents in a lump sum. Nevertheless, a reduction in the corporate tax rate may make the country that imposes the tax worse off.

For example, if the oligopolistic sector is capital intensive, a reduction in the corporate tax rate increases unemployment, which is harmful to the country. Moreover, if the country has a low equity share, little of the extra profit deriving from the reduction in corporate tax returns to the country. The volume of home demand for the oligopolyproduced commodity (or that of consumer surplus) and the number of domestically based oligopolists also influence the welfare effect of the tax reduction through a change in the price and through a rise in the tax burden, respectively.

\section{Mathematical Appendix}

From (2), (3), and (17), we obtain

$$
\left.L_{o \theta}\right|_{\theta=\theta^{*}}=\frac{n^{*} x}{2(1-\theta)(1+N) g},\left.\quad L_{o \theta^{*}}\right|_{\theta=\theta^{*}}=-\frac{(1+n) x^{*}}{2\left(1-\theta^{*}\right)(1+N) g} .
$$

When $\theta=\theta^{*}$, equations (2) and (17) yield

$$
x_{\theta}^{*} d \theta+x_{\theta^{*}}^{*} d \theta^{*}=g d L_{o}^{*}+L_{o}^{*} g^{\prime} d k_{o}^{*} .
$$

From (5),

$$
\begin{gathered}
d\left(\frac{w^{*}}{r^{*}}\right)=-\frac{g\left(k_{o}^{*}\right) g^{\prime \prime}\left(k_{o}^{*}\right)}{\left(g^{\prime}\left(k_{o}^{*}\right)\right)^{2}} d k_{o}^{*}, \\
d c\left(w^{*}\right)=\frac{f^{\prime \prime}\left(k_{o}^{*}-k_{a}^{*}\right)}{g} d k_{a}^{*}=\frac{r^{*} g^{\prime \prime}\left(k_{o}^{*}-k_{a}^{*}\right)}{\left(k_{a}^{*}+\frac{w^{*}}{r^{*}}\right)\left(g^{\prime}\right)^{2}} d k_{o}^{*} .
\end{gathered}
$$

Equations (8) and (17) lead to

$$
-\frac{p^{\prime} x}{2(1-\theta)} d \theta+\frac{p^{\prime} x^{*}}{2\left(1-\theta^{*}\right)} d \theta^{*}=d c\left(w^{*}\right) .
$$

From (A-2), (A-3) and (A-4),

$$
\left.k_{a \theta}^{*}\right|_{\theta=\theta^{*}}=-\frac{g p^{\prime} x}{2(1-\theta) f^{\prime \prime}\left(k_{o}^{*}-k_{a}^{*}\right)},\left.\quad k_{a \theta^{*}}^{*}\right|_{\theta=\theta^{*}}=\frac{g p^{\prime} x^{*}}{2\left(1-\theta^{*}\right) f^{\prime \prime}\left(k_{o}^{*}-k_{a}^{*}\right)},
$$




$$
\begin{gathered}
\left.k_{o \theta}^{*}\right|_{\theta=\theta^{*}}=-\frac{p^{\prime} x\left(k_{a}^{*}+\frac{w^{*}}{r^{*}}\right)\left(g^{\prime}\right)^{2}}{2(1-\theta)\left(k_{o}^{*}-k_{a}^{*}\right) r^{*} g^{\prime \prime}},\left.\quad k_{o \theta^{*}}^{*}\right|_{\theta=\theta^{*}}=\frac{p^{\prime} x^{*}\left(k_{a}^{*}+\frac{w^{*}}{r^{*}}\right)\left(g^{\prime}\right)^{2}}{2\left(1-\theta^{*}\right)\left(k_{o}^{*}-k_{a}^{*}\right) r^{*} g^{\prime \prime}}, \\
\left.L_{o \theta}^{*}\right|_{\theta=\theta^{*}}=\frac{x_{\theta}^{*}}{g}+\frac{p^{\prime} x\left(k_{a}^{*}+\frac{w^{*}}{r^{*}}\right) L_{o}^{*}\left(g^{\prime}\right)^{3}}{2(1-\theta)\left(k_{o}^{*}-k_{a}^{*}\right) r^{*} g g^{\prime \prime}}, \\
\left.L_{o \theta^{*}}^{*}\right|_{\theta=\theta^{*}}=\frac{x_{\theta^{*}}^{*}}{g}-\frac{p^{\prime} x^{*}\left(k_{a}^{*}+\frac{w^{*}}{r^{*}}\right) L_{o}^{*}\left(g^{\prime}\right)^{3}}{2\left(1-\theta^{*}\right)\left(k_{o}^{*}-k_{a}^{*}\right) r^{*} g g^{\prime \prime}} .
\end{gathered}
$$

Applying (A-1) and (A-5) to (12) and making use of (14) gives (20) and (23). Substituting $k_{a \theta}^{*}$ and $k_{a \theta^{*}}^{*}$ in (A-5) into (16), respectively, and making use of (2) yields (21) and (24).

From (2), (3), and (26),

$$
L_{o s}=\frac{x_{s}}{g}, \quad d L_{o}^{*}=\frac{x_{s}^{*}}{g} d s-\frac{g^{\prime} L_{o}^{*}}{g} d k_{o}^{*} .
$$

Because (5) and (A-3) hold in this case, using these equations together with the first line in $(26)$ and (A-6), one finds

$$
\begin{gathered}
L_{o s}^{*}=\frac{x_{s}}{g\left(k_{o}^{*}\right)}-\frac{\left(g^{\prime}\right)^{3} L_{o}^{*} k_{a}^{*} w^{*}}{\left(k_{a}^{*}-k_{o}^{*}\right) g g^{\prime \prime} r^{*}}\left(\frac{1}{w^{*}}+\frac{1}{r^{*} k_{a}^{*}}\right), \quad L_{o s^{*}}^{*}=\frac{\left(g^{\prime}\right)^{3} L_{o}^{*} k_{a}^{*} w^{*}}{\left(k_{a}^{*}-k_{o}^{*}\right) g g^{\prime \prime} r^{*}}\left(\frac{1}{w^{*}}+\frac{1}{r^{*} k_{a}^{*}}\right), \\
k_{a s}^{*}=\frac{g}{f^{\prime \prime}\left(k_{a}^{*}-k_{o}^{*}\right)}, \quad k_{a s^{*}}^{*}=-\frac{g}{f^{\prime \prime}\left(k_{a}^{*}-k_{o}^{*}\right)}, \\
k_{o s}^{*}=\frac{\left(g^{\prime}\right)^{2} k_{a}^{*} w^{*}}{g^{\prime \prime}\left(k_{a}^{*}-k_{o}^{*}\right) r^{*}}\left(\frac{1}{w^{*}}+\frac{1}{r^{*} k_{a}^{*}}\right), \quad k_{o s^{*}}^{*}=-\frac{g^{\prime} k_{a}^{*} w^{*}}{g^{\prime \prime}\left(k_{a}^{*}-k_{o}^{*}\right) r^{*}}\left(\frac{1}{w^{*}}+\frac{1}{r^{*} k_{a}^{*}}\right) .
\end{gathered}
$$

Applying the values in (A-6) and (A-7) to (12) and making use of (14) leads to (28) and the first property of (31). Substituting $k_{a s}^{*}$ and $k_{a s^{*}}^{*}$ in (A-7) into (16) yields (29) and the second property of (31), respectively.

\section{References}

Brander, J. A. and B. J. Spencer (1985) "Export Subsidies and International Market Share Rivalry," Journal of International Economics 18, 83-100.

Exbrayat, N., C. Gaigné and S. Riou (2012) "The Effects of Labour Unions on International Capital Tax Competition," Canadian Journal of Economics 45, 1480-1503.

Johdo, W. and K. Hashimoto (2009) "International Relocation, the Real Exchange Rate and Effective Demand," Japan and the World Economy 21, 39-54.

Kreickemeier, U. (2005) "Unemployment and the Welfare Effects of Trade Policy," Canadian Journal of Economics 38, 194-210.

Leite-Monteiro, M., M. Marchand and P. Pestieau (2003) "Employment Subsidy with Capital Mobility," Journal of Public Economic Theory 5, 327-344. 
Hamada, Y. (2008) "Hojokin Oyobi Sono Katsuyou Jirei to Kigyo Yuuchi Suisin (in Japanese)," Shoko Research Institutes.

Haufler, A. and F. Mittermaier (2011) "Unionisation Triggers Tax Incentives to Attract Foreign Direct Investment," Economic Journal 121, 793-818.

Haufler, U. and F. Stähler (2013) "Tax Competition in a Simple Model With Heterogeneous Firms: How Larger Markets Reduce Profit Taxes," International Economic Review 54, 665-692.

Hucka, S. and K. A. Konrad (2003) "Strategic Trade Policy and the Home Bias in Firm Ownership Structure," Japan and the World Economy 15, 299-305.

Lahiri, S. and Y. Ono (1995) "The Role of Free Entry in an Oligopolistic HeckscherOhlin Model," International Economic Review 36, 609-624.

Lahiri, S. and Y. Ono (2011) "An Oligopolistic Heckscher-Ohlin Model of Foreign Direct Investment," Japanese Economic Review 62, 331-347.

Ogawa, H., Y. Sato and T. Tamai (2006) "A Note on Unemployment and Capital Tax Competition," Journal of Urban Economics 60, 350-356.

Tax Foundation Website (2013) "OECD Corporate Income Tax Rates, 1981-2013," http://tax foundation.org/article/oecd-corporate-income-tax-rates-1981-2013.

Wildasin, D. E. (1988) "Nash Equilibrium in Models of Fiscal Competition," Journal of Urban Economics 35, 229-240.

Wilson, J. D. (1986) "A Theory of Inter-Regional Tax Competition," Journal of Urban Economics 19, 296-315. 